\title{
APPLICATION OF SOFTWARE PACKAGES IN RESEARCH AND DIDACTICS
}

\author{
Pawel Ptak \\ Czestochowa University of Technology, Faculty of Electrical Engineering, Poland
}

\begin{abstract}
The paper describes software packages National Instrument Multisim and DasyLab. The former can be applied for designing, testing and simulations of electronic and digital elements and systems. The latter is used for designing virtual measuring systems for obtaining measuring data from real objects and measuring sensors. Both software packages can be fruitfully applied in research and in the teaching of technology-related subjects. The paper presents examples of both kinds of applications of the software under scrutiny.
\end{abstract}

Keywords: software packages, simulation, teaching.

\section{Introduction}

The idea that computer tools should be used in metrology research and didactics has been increasingly popular over the recent years. The software packages offer many advantages and benefits, which are useful in taking and analysing measurements. There are two basic kinds of software: that for obtaining and processing measuring data and that for simulating and modelling electronic and digital systems (Winiecki, 2001; Rak, 1999).

The software package DasyLab belongs to the first category. It is used for designing a measuring environment in the form of a block diagram, with blocks connected in accordance with the data flow paths. Each functional block is represented as an icon by means of which its parameters and setting can be modified at any time. The functional blocks can be connected in a number of ways to create a unique measuring system, which can be modified, extended or connected to other measuring systems performing other functions. The measuring data can be obtained from a measuring card of a real object or, alternatively, a simulated measuring signal can be used. This can be advantageous when access to the real object is limited or when it is necessary to test the operation of the measuring system while it is being designed and constructed. It is possible to perform a number of mathematical or statistical operations on the real or simulated data (Ptak \& Borowik, 2012). The results obtained can be represented in a variety of ways and saved in files so that they can be further processed in specialised data analysis programmes or used for expanding the measuring system (Prauzner \& Ptak, 2014; Ptak \& Prauzner, 2013). 
The Multisim Education software manufactured by National Instruments belongs to the other category of programmes. The software can be used for constructing measuring systems and test systems out of ready-made electronic and digital elements implemented in the programme. It is possible to test the operation of a system under scrutiny by analysing output signals and examining the operation of the simulated system. Depending on the preferences, one can use models of real electronic elements or models with idealised parameters. Both types of models can be combined in one measuring system and they can be differentiated by using separate colours for the particular elements and data flow paths. The system is also equipped with virtual counterparts of measuring instruments, including the image of the front panel, as well as control elements.

The two software packages are in many ways complementary. Multisim education is a programme for constructing and simulating electronic and digital systems, which can be used for constructing and simulating electronic and digital systems, which in turn can be further applied for constructing support electronic systems for the preliminary processing of data collected by measuring sensors. The main function of the programme DasyLab is to acquire and process data from existing measuring systems. The software can also be used for carrying out fully automatic measuring processes (Ptak \& Borowik, 2014). With both software packages combined, Multisim Education can be utilised for designing an electronic system for the preliminary processing of a measuring signal, whereas DasyLab provides tools for more complex and fine-tuned processing of the results as well as comprehensive control over the measuring system and testing. Both software packages offer a possibility of designing a simulated measuring system at a preliminary stage of work and then turning it into a real system applied for performing measurements and tests (Ptak \& Borowik 2015).

\section{Applications of the software packages Multisim and DasyLab}

A number of electronic systems were constructed by means of Multisim in order to design electronic filters. They were built using operational amplifiers working in various systems and performing the functions of low-pass and bandpass filters. The figures below present screenshots from the Multisim software, first with elements used in the simulations and then of the complete measuring systems. Figure 1 presents a screenshot with the electronic elements selected for the simulation. They were utilised for the construction of all the filter systems, to which some additional components characteristic of a specific system were also supplemented. 
Proceedings of the International Scientific Conference. Volume II, May $27^{\text {th }}-28^{\text {th }}$, 2016. 589-597

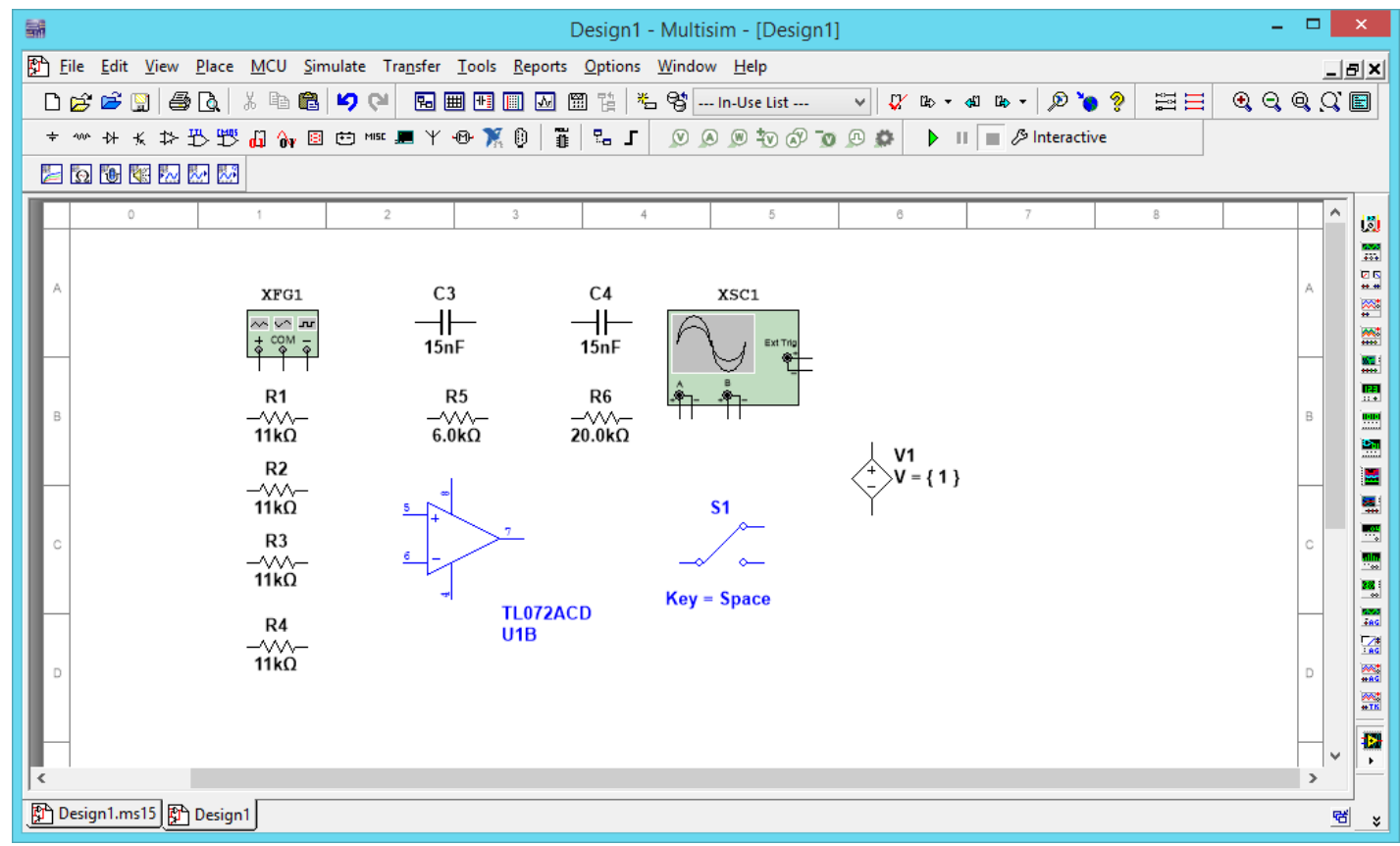

Figure 1 Electronic elements used in the Multisim simulation

Figure 2 presents a diagram of the low-pass filter constructed on the basis of the operational amplifier.

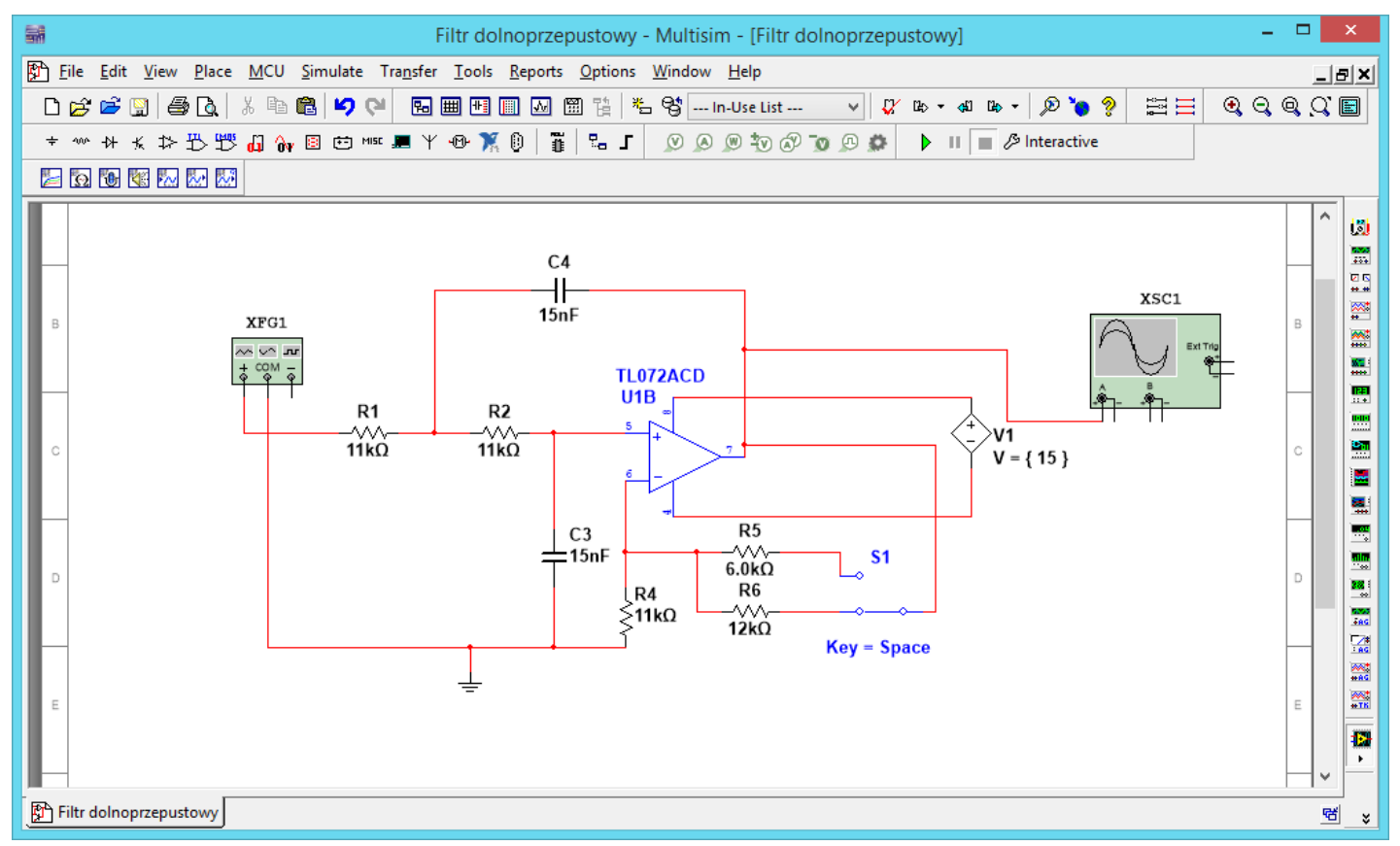

Figure 2 The low-pass filter system constructed by means of Multisim 
Figure 3 presents an ongoing simulation of the system, control elements of the functional generator and the output signal displayed on the in-built oscilloscope.

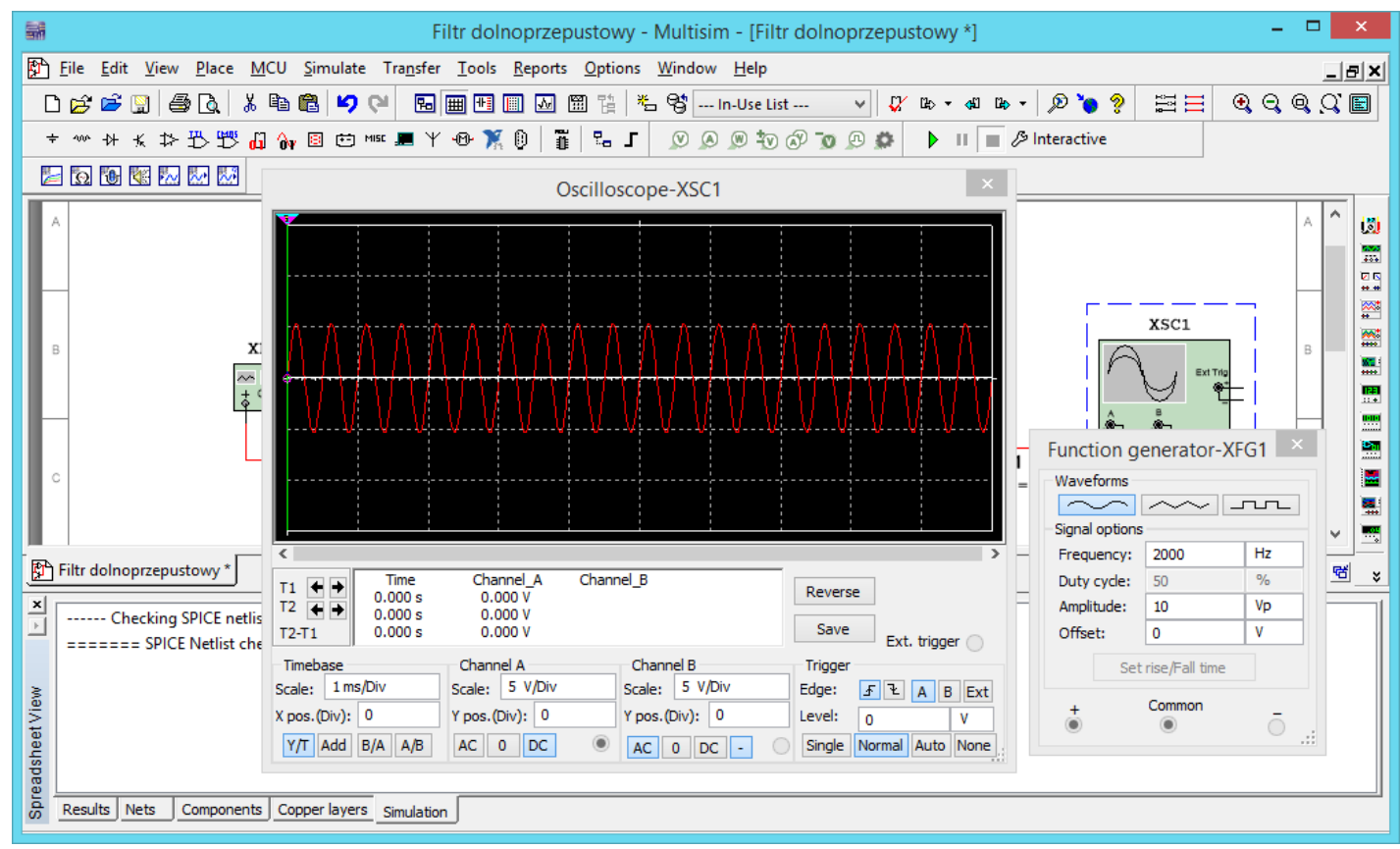

Figure 3 Simulation for the low-pass filter in Multisim

A diagram of the electronic system performing the function of the bandpass filter is presented in Figure 4.

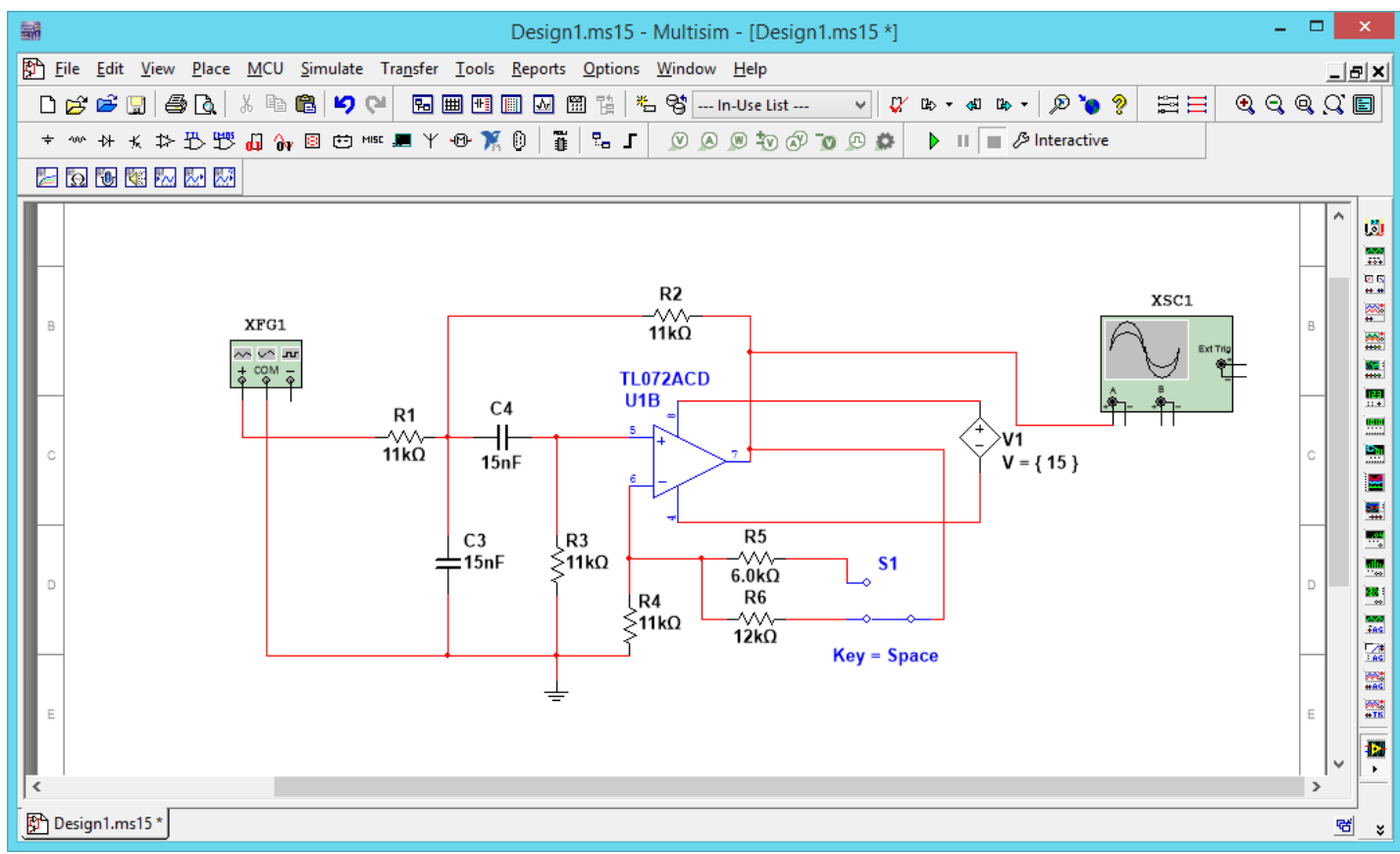

Figure 4 The band-pass filter system constructed by means of Multisim 
Figure 5 presents a view of the on-going simulation of the system, including the filter output signal and the control elements of the oscilloscope and of the functional generator.

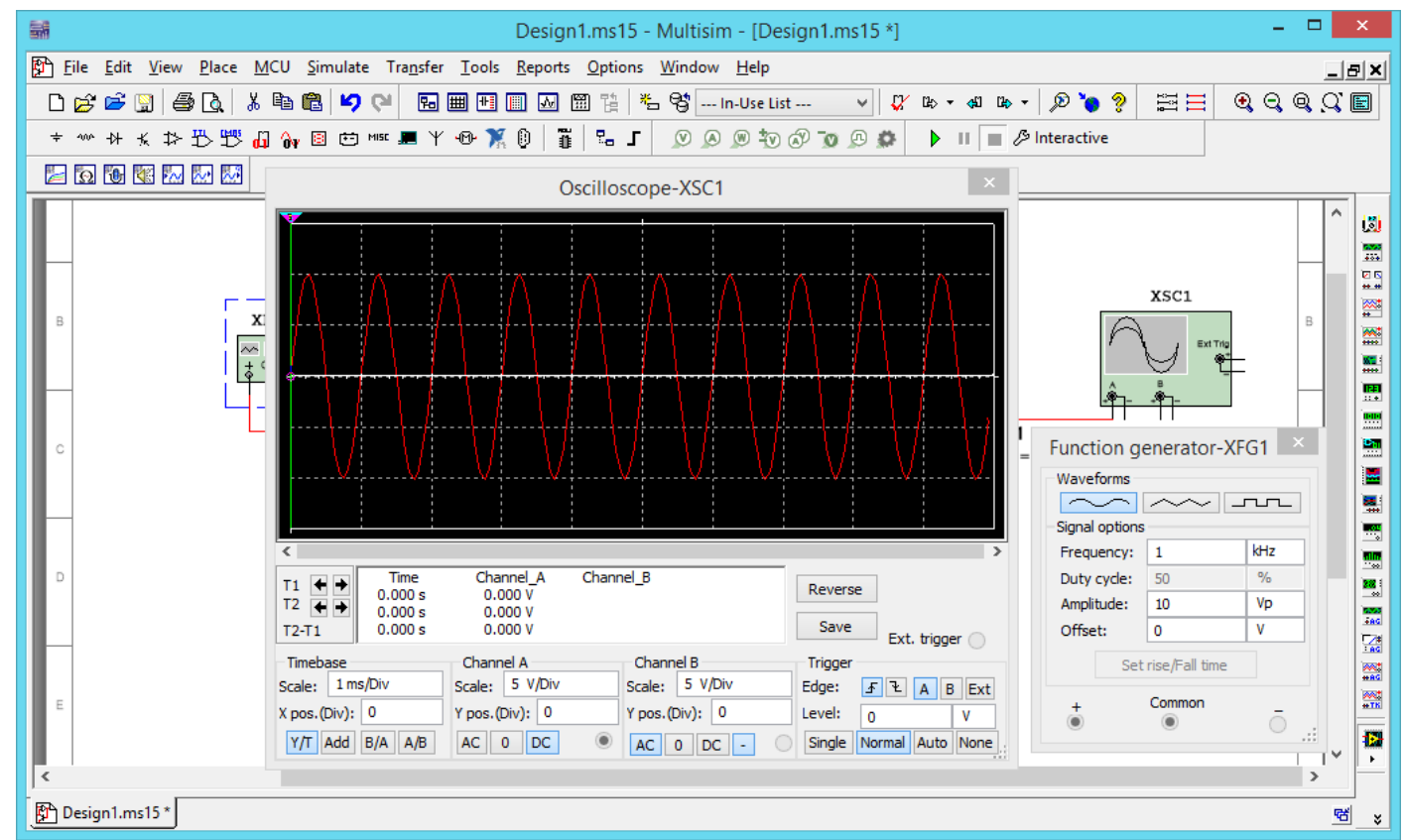

Figure 5 Simulation for the band-pass filter in Multisim

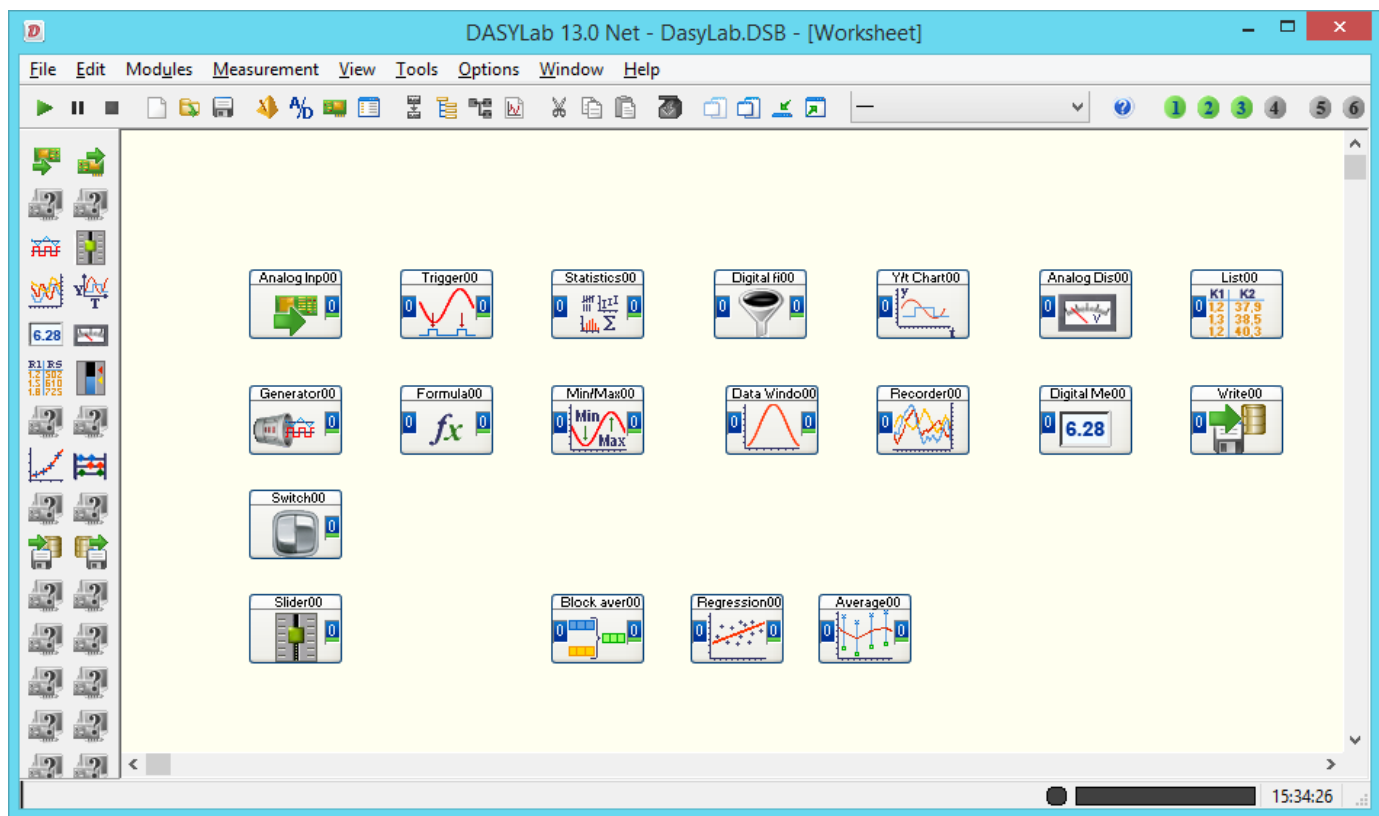

Figure 6 Functional modules applied for the simulation in DasyLab

A number of simulations for a measuring system were also carried out in the DasyLab software. More specifically, this software was used for constructing a measuring system for examining the parameters of a signal 
varying in time. Figure 6 presents a screenshot of DasyLab with the icons representing the functional modules applied in the simulation.

Figure 7 presents a simple version of the measuring system simulating a measuring signal which can be adjusted in a broad range of parameters and represented as a time waveform on the software's built-in oscilloscope.

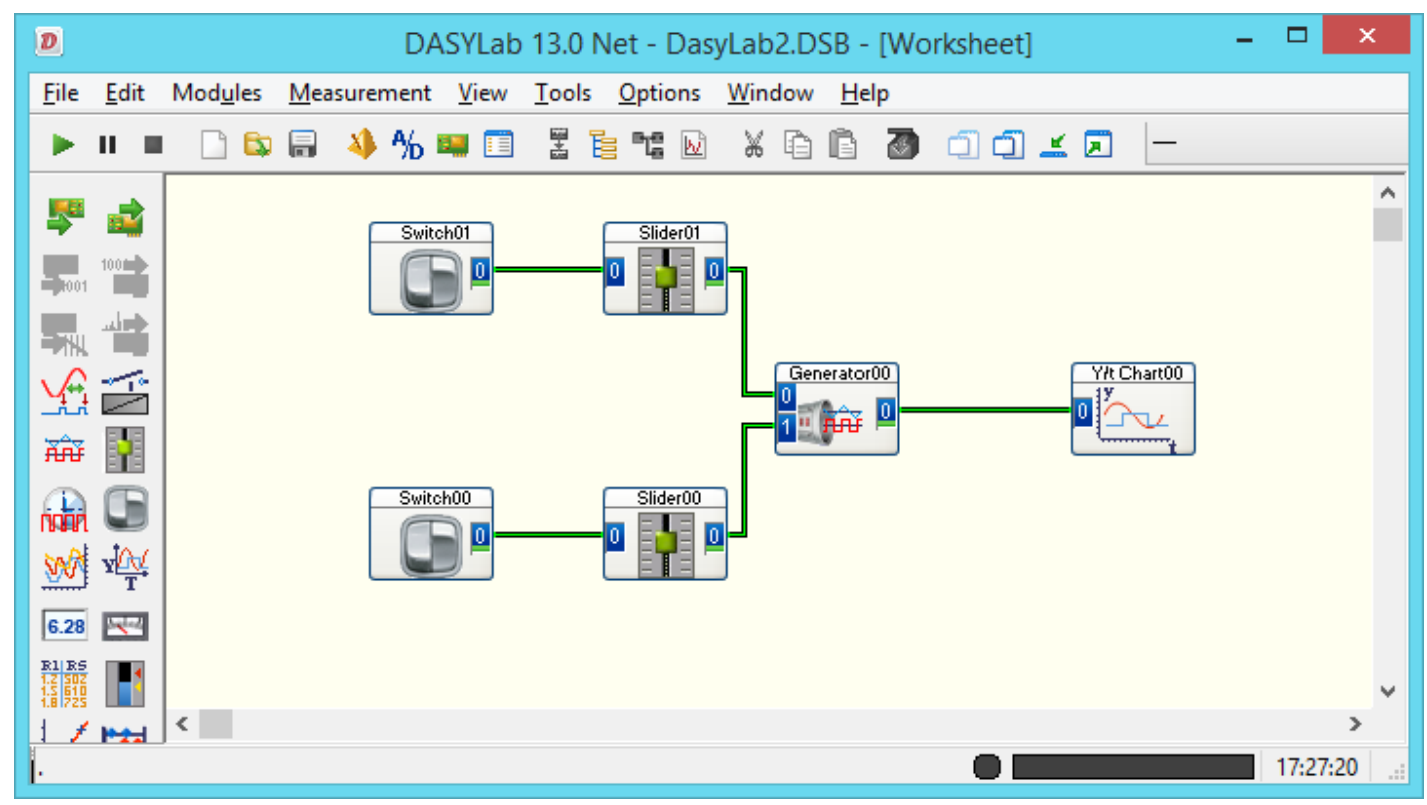

Figure 7 A measuring system constructed using DasyLab

The system was subsequently expanded by adding a two-step filter for noise reduction in the generated signal. Additionally, the generated signal was pre-processed by amplifying a low-amplitude weak signal. The modified version of the measuring system is presented in Figure 8.

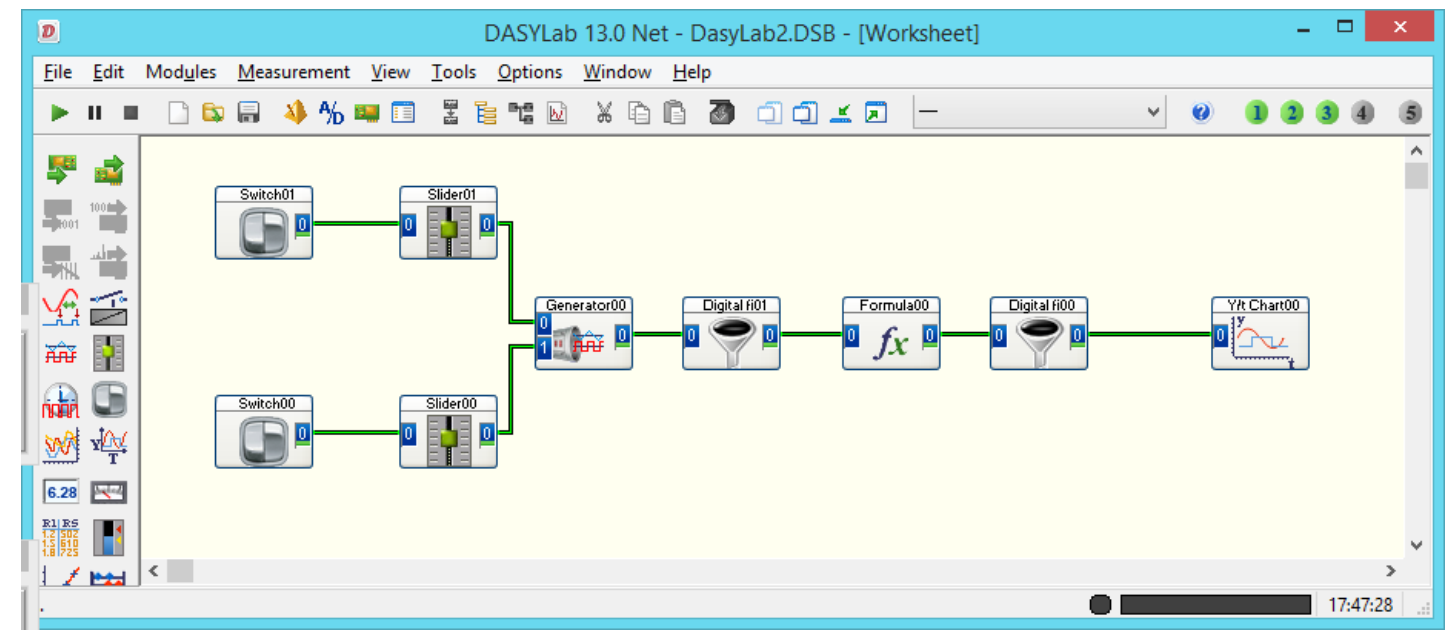

Figure 8 Modified version of the measuring system constructed using DasyLab 
Figure 9 presents an expanded measuring system, with an additional statistical module and two modules for averaging the measuring results on the basis of the time waveform and on the basis of a larger portion of measuring data. Such modules are applied in order to eliminate random errors and noise. The measuring system is shown during performing of a simulation, together with control elements and panels displaying calculated results of the input signal.

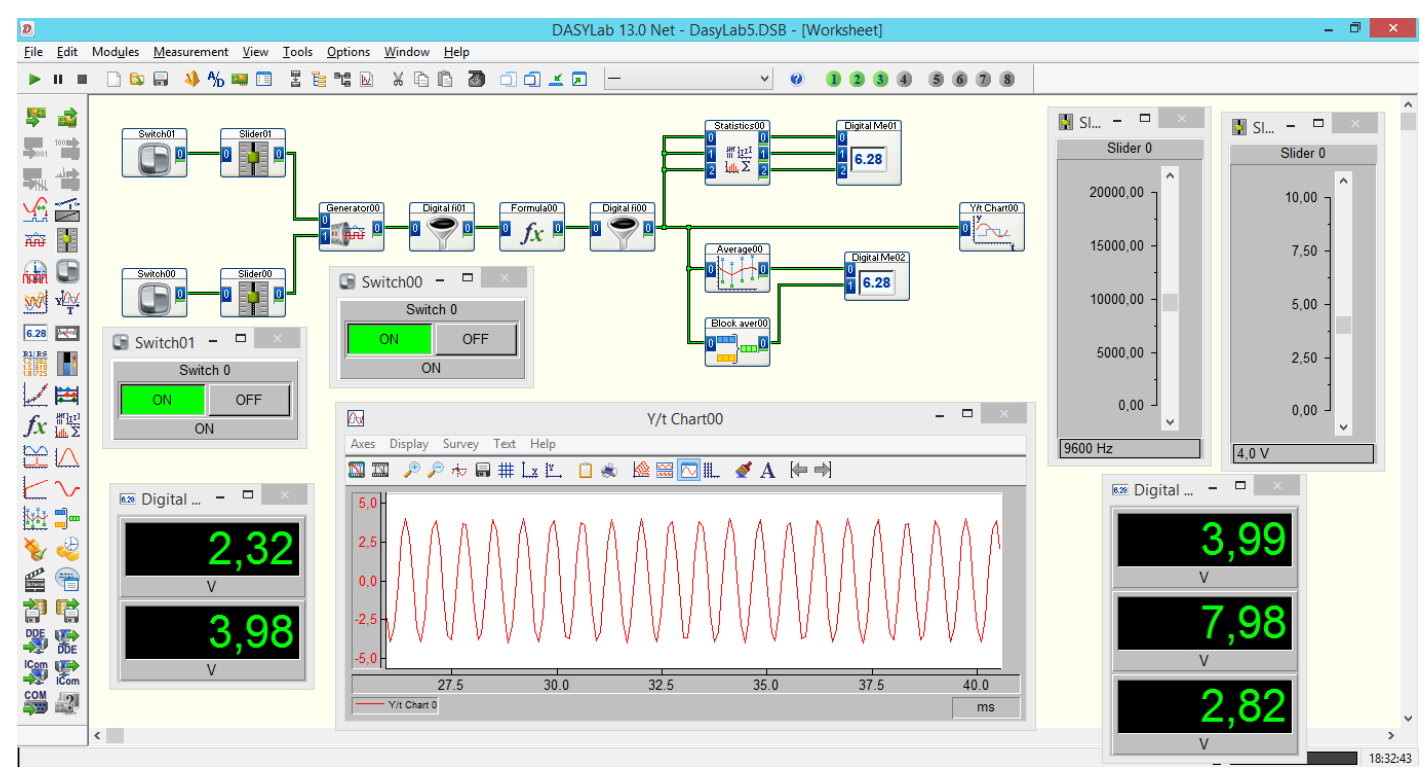

Figure 9 Expanded measuring system during operation in DasyLab

In the didactics of engineering subjects, simulation is a very popular method of modelling various processes and systems (Prauzner, 2014; Prauzner, 2015; Zloto et al., 2012). It can be a form of a laboratory task for students, who have to verify the model on the basis of simulation results (Prauzner, 2012; Prauzner, 2014). Simulation can also be used for assessing teaching methods applied in technical universities (Depesova et al., 2008; Noga, 2009; Noga et al., 2014).

\section{Concluding remarks}

- Software packages such as Multisim and DasyLab offer cost saving and easily available opportunities for designing and simulating measuring systems to be used for didactic purposes.

- The applications can be expanded and adjusted to the specific needs of a task by connecting a measuring card (or some other device) to the computer. 
- It is possible to verify the operation of the designed measuring system by performing a simulation within the environment of the software (Multisim or DasyLab), without altering the hardware setup.

- The measuring system is flexible can be modified both in the laboratory and outside of it, both by the class instructor preparing a task and by students performing their self-studies (Prauzner, 2015).

\section{References}

Depesova, J., Vargova, M., \& Noga, H. (2008). Edukacja techniczno informatyczna w opinii nauczycieli. Uniwersytet Pedagogiczny, Kraków, 149-157.

Noga, H. (2009). Sociometric methods in technological and information technology education. In: Trends in Education. Information technologies and technical education. Olomouc, Vols.1, 165-169.

Noga, H. Piaskowska-Silarska, M., Depešová, J., Pytel, K., \& Migo P. (2014). Neuro didactic erspective of creative attitude towards education in the third millennium examination of individual cases. In: Emerging eLearning Technologies and Applications (ICETA), 2014 IEEE 12th International Conference on, 355 - 360.

Prauzner, T. (2012). Zakłócenia elektromagnetyczne w elektronicznych systemach alarmowych. Przeglad Elektrotechniczny, NR 12b/2012, 205-208.

Prauzner, T. (2014). Effectiveness of magnetic detectors in alarm systems. Przeglad Elektrotechniczny, R. 90 NR 12/2014, 269-272.

Prauzner, T., \& Ptak, P. (2014). Analiza parametrów pracy wybranych czujników pola magnetycznego. Przeglad Elektrotechniczny, R. 90 NR 12/2014, 273-276.

Prauzner, T. (2014). Modelowanie działania czujki magnetycznej w programie Quckfield jako przykład wykorzystania e-technologii w metrologii elektrycznej. Zeszyty Naukowe Wydziału Elektrotechniki i Automatyki Politechniki Gdańskiej $\mathrm{Nr}$ 37, E-Technologies in Engineering Education, Politechnika Gdańska, 125-129.

Prauzner, T. (2015). Analysis of the Results of the Pedagogical Research and Eeg in the Aspect of Effective Modern Teaching Aids in the Technical Education. In: Society, Integration, Education. Proceedings of the International Scientific Conference, 480490.

Prauzner, T. (2015). Finite Element Method in an analysis of selected parameters of an inductive sensor for protective coatings measurements. Przeglad Elektrotechniczny, 91 (2015), $n r .12, .205-208$.

Ptak, P., \& Borowik, L. (2012). Diagnostyka zabezpieczeń antykorozyjnych na potrzeby elektroenergetyki. Przeglad Elektrotechniczny, nr 09a, 142-145.

Ptak, P., \& Prauzner, T. (2013). Badanie czujników detekcji zagrożeń w systemach alarmowych. Przeglad Elektrotechniczny, NR 10/2013, 274-276.

Ptak, P., \& Borowik, L. (2014). Dokładność czujników indukcyjnych w defektoskopii warstw ochronnych urządzeń elektrycznych. Przegląd Elektrotechniczny, R. 90 NR 12/2014, 277-280.

Ptak, P., \& Borowik, L. (2015). Badanie wielowarstwowych powłok ochronnych. Przeglad Elektrotechniczny, R. 91 NR 12/2015, 209-211.

Rak, J. R. (1999). Wirtualne przyrządy pomiarowe. Białystok, XXXI Międzyuczelniana Konferencja Metrologów MKM’99. 
Winiecki, W. (2001). Graficzne zintegrowane środowiska programowe. Warszawa, PL: Wyd. Mikom.

Zloto, T., Ptak, P., \& Prauzner, T. (2012). Analysis of signals from inductive sensors by means of the DasyLab software. Annales Universitatis Mariae Curie-Skłodowska Sectio AI Informatica XII, NR 1/2012, 31-37. 